\title{
1 de julho
}

Pedro Naletto

Pode-se dizer que ela é como certos contos de Cortázar. Completamente confusa, mas de uma confusão que não me impede de compreendê-la. Pelo contrário, é justamente a forma como ela te conquista, ou, no caso do conto, a forma como a narrativa te envolve. Um inegável quê de genialidade. A princípio, sua forma me parece estranha e seu conteúdo, obscuro, não é algo que possa ser apreendido de imediato, não encaixa à primeira vista. Requer uma certa insistência. Quando, finalmente, percebo a genialidade encoberta sob a forma, situada lá, no encontro entre os pequenos detalhes e o todo, emudeço. Minha cabeça já foi capaz de compreender o modo como as coisas se ligam e a beleza que há em tudo isso, mas ainda estou longe de conseguir tecer algum comentário sobre. Então, tudo que faço é me entregar a um longo suspiro que termina em um tímido sorriso. Quem vê de fora não imagina, mas está aí a mais pura expressão de algo que não conseguirei transpor exatamente em palavras.

Tudo isso é muito bonito, mas o interessante é que, não sendo você a criação de um excelente autor, nem de qualquer autor, não há motivos para que a sua confusão faça o mesmo sentido dos contos. Por muitas vezes, indaguei-me se o sentido não estava na minha cabeça em vez de no seu mundo. Não sei aonde queria chegar com isso, mas sei que não cheguei longe. No 
fundo, por mais louco que eu seja, só você pode ser a causa do que me atrai a você. Não que seja algo assim deliberado, consciente, mas convenhamos que não pode ser mera aleatoriedade, pode? Talvez seja só um encaixe do que eu desejo com o que você é; mas todo mundo tem alguma culpa de ser o que é. Bom, mera aleatoriedade sei que não pode ser, em meio a tantas pessoas que gostam do que eu gosto, riem do que eu rio, e, ainda assim, não me fazem suspirar; ou em meio a tanta gente cujos pequenos detalhes eu percebo, mas que só servem pra me tirar do sério, você aparece, fazendo-me sorrir até quando penso no que me irrita no seu jeito.

Divagações à parte, você nunca apreciou muito os meus interesses filosóficos, e tem lá seus motivos. A forma sensível como você exerce esse poder de me trazer para o chão é impressionante. Os dedos subindo pela minha nuca e entrando no meu cabelo, minha cabeça sendo levemente conduzida para trás. Mal sabe Descartes que me basta você para pôr em dúvida a separação entre corpo e alma. Você odeia esse tipo de piada. E qual não foi a minha surpresa ao reparar no seu computador aberto, enquanto você passava uma de suas longas estadias no banheiro. Vai ver que você fica escrevendo enquanto está lá, nunca soube que você escrevia coisas desse tipo. Sei bem que você adora Cortázar e por isso fico lisonjeada, mas confesso que ainda não processei essa história de ser confusa. Aliás, o que eu não gosto mesmo é quando você vem com o seu papo de que tenho que lê-lo no original, que não é a mesma coisa. Tudo bem que não seja, mas fazer o quê? Crime e Castigo é um dos meus livros favoritos e nem por isso pretendo lê-lo em russo.

Espero que não se importe com a minha intromissão. Seu texto me pareceu tão espontâneo que resolvi tentar também. Não pude deixar de pensar, parece-me que lhe é muito mais fácil se expressar nesta página em branco do que em palavras faladas, ou melhor, trocadas. Pode ser uma boa ideia para nós trocar certas coisas por meio de cartas. Pode ser bom pensarmos com calma no que queremos dizer e na forma como seremos entendidos. Alguns assuntos certamente serão mais fáceis de serem tratados dessa forma. Consigo até imaginar você escrevendo algo, esforçando-se para introduzir certo assunto, para no fim desistir de me dizer. Talvez você deixe guardado, talvez apague tudo. A expectativa pela próxima carta pode até ser algo excitante.

Ela o ouviu desligando o chuveiro e terminando de se trocar, mas a intromissão já estava consumada, de nada adiantaria fingir. Ao sair do banheiro, ficou discretamente surpreso ao vê-la. Cumprimentou-a com um beijo curto e disse que não a havia ouvido entrar em casa. Você viu no que eu estava trabalhando? Ela consentiu com a cabeça. Você leu? Novamente ela acenou. Pareceu-me que você consegue criar uma ligação bem fluida 
entre o pensamento e o papel. Tentei escrever algo também e continuei seu próprio texto, mas ainda não salvei. Não escrevi muito, mas acho me ajudou a digerir o que tinha lido. Espero que não se incomode, realmente gostei do que você escreveu. Você sempre teve um jeito delicado de dizer as coisas, fazia tempo que você não me dizia coisas assim. Ela ficou apreensiva enquanto fingia olhar para o computador, mas sentiu-se leve ao levantar a cabeça e vê-lo sorrindo. Fico feliz que tenha gostado, quero ler o que você acrescentou. Mistura de dois textos, deve ter ficado uma confusão só. Tinha receio de mostrar a você o que tenho escrito, mas talvez uma parte de mim tenha deixado o documento aberto de propósito. Sabe, comecei a escrever há pouco mais de um ano, não escrevo com tanta periodicidade e nem tudo é sobre você, mas recentemente reparei que esse ímpeto de escrever coisas que ninguém vai ler surgiu à medida que nos distanciamos. É como se a escrita fosse, para mim, um substituto barato para as longas conversas que costumávamos ter até então. Você lembra de como passávamos horas conversando em casa e como éramos capazes de perceber, logo de cara, se a conversa seria longa, leve ou cabeçuda? Era incrível como às vezes um de nós, por qualquer motivo, acabava por se concentrar em outra coisa, mas permanecia exercendo sua função na conversa. Muitas vezes tudo que o outro precisava era organizar seus próprios pensamentos, e para tal bastava um interlocutor. Hoje em dia tento escrever diálogos, mas nunca estive com a mente tão confusa. Você não é como conto nenhum, você não é pensada, não é obra de ninguém. Você não faz sentido e nem deveria fazer. Você é como o próprio Cortázar, capaz de brincar com as formas e se reinventar, testando os limites da compreensão para além do possível. É como se toda a sua genialidade fosse uma estratégia espontânea, um modo inconsciente de não cair no óbvio, de manter uma certa profundidade que, como sabe, deixa sem fôlego quem quer que a perceba. Meu amor. Indo até o pé da cama, onde ele se encontrava, ela lhe acariciou o cabelo por sobre a orelha e lhe deu um delicado beijo, que se demorou durante um tempo, os lábios quase não se movendo. A comunicação verbal não havia sido a única afetada pelo distanciamento. A antiga sincronia do beijo, o sincretismo alcançado no amor, há tempos não eram mais os mesmos. O cuidado de um café e o carinho de um doce também já não eram mais vistos. Ele podia agora sentir o cheiro dela e a textura das minúsculas rachaduras do seu lábio, enquanto ela lhe acariciava o rosto, descendo pela nuca até dobrar a mão em seu pescoço. Eles foram, lentamente, se redescobrindo, retomando as longas conversas, mas começando por onde sentiram ser mais fácil, pelo que é essencial. Os lábios começaram a se mover, as línguas seguiram o ímpeto. Braços e per- 
I de julho

nas também, movendo-se em carícias e encaixes. Lentamente caminharam, conseguindo entender-se, expressar-se, cada vez mais. A conversa durou a noite toda sem que mais nenhuma palavra fosse dita.

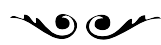

Pedro Naletto é graduando em Filosofia pela Universidade de São Paulo. pedro.naletto@usp.br 